\title{
Application of alternative treatments to control postharvest fungal infection and shelf life extension of papaya in different maturity stages
}

\author{
MHA Rashid ${ }^{1 *}$, BC Borman ${ }^{1}$, MS Islam², and A Shirin ${ }^{3}$ \\ ${ }^{1}$ Department of Horticulture, Bangladesh Agricultural University, Mymensingh 2202, Bangladesh; ${ }^{2}$ Department of \\ Agriculture, Noakhali Science and Technology University, Sonapur, Noakhali, Bangladesh; ${ }^{3}$ Department of Plant \\ Pathology, Bangladesh Agricultural University, Mymensingh 2202, Bangladesh.
}

\begin{abstract}
An experiment was conducted to study the application of alternative treatments to control postharvest fungal infection and shelf life extension of papaya under different maturity stages at the Laboratories of the Department of Horticulture and Agricultural Chemistry, Bangladesh Agricultural University, Mymensingh during the period from August to October, 2018. The two factor experiment (maturity stages and postharvest treatments) was laid out in a completely randomized design (CRD) with three replications. Four postharvest treatments viz., control, hot water treatment (Fruits treated at $50 \pm 2^{\circ} \mathrm{C}$ for 10 minutes), chitosan coating (2000ppm chitosan solution) and hot water+chitosan coating were assigned to papaya fruits which were maturity stage I or maturity stage II. Significant variations were observed between maturity stage I (green mature) and maturity stage II (0-10\% yellowing of fruits) in relation to most of the parameters studied. Results showed that most of the parameters studied were significantly influenced by the afore-mentioned factors. Longer shelf life (12.64 days) was observed in maturity stage I fruits than maturity stage II fruits (12.18 days). Significant reduction in disease incidence and severity was noticed in the maturity stage I fruits as compared to maturity stage II fruits. The longest shelf life (15.20 days) was found in hot water treated and chitosan coated fruits of maturity stage I, whereas the shortest shelf life (8.52 days) was observed in control of maturity stage II fruits.
\end{abstract}

Key words: Papaya, maturity stage, hot water, chitosan, diseases, shelf life

Progressive Agriculturists. All rights reserved

*Corresponding Author: harun_hort@bau.edu.bd

\section{Introduction}

In Bangladesh papaya is the most common and wanted fruit, which belongs to the familyCaricaceae. Carica papaya $\mathrm{L}$. is the most important and cultivated all over the world (Badillo,1971). Papaya is a major fruit crop worldwide that is primarily consumed as fresh. Papaya is a nutritious table fruit of high digestive value which consists mostly of water and carbohydrate and low in calories. It is an excellent source of natural vitamins and minerals, particularly vitamins $\mathrm{A}$ and $\mathrm{C}$, ascorbic acid, calcium and potassium (Chan and Tang, 1979).
Papaya is also used to produce different tropical medicine.

Though origin is unknown, papaya is believed native to tropical America, perhaps in southern Mexico and neighbouring Central America (Singh 1990). A large number of papaya varieties are widely grown in Bangladesh. In Bangladesh, papaya occupied 3942 acres of land and total production was about 134647 tones with an average yield of 34.15 tones per acre (BBS, 2017). Reports claim that about $30-50 \%$ of the 
harvested papaya never reaches the consumers mainly because of postharvest spoilage (Mondal and Bose, 2007). If that amount of fruit were equally distributed among the total people of Bangladesh, the per capita availability of fruit is far below the recommended level $(100 \mathrm{~g} /$ capital). The residual analysis of fruits also showed the quality of any fruits, which is very important for the quality of fruit- as a mirror from production to post-harvest processes (Islam et al., 2015). The climacteric fruits are attributed to adverse physio-chemical changes, namely losses of weight due to respiration and transpiration, reducing sugar, nonreducing sugar, total soluble solids (Islam et al., 2011).

Papaya is a climacteric fruit and highly perishable because of fast ripening which trigger ethylene production and that's why its consumption period is very short after harvesting at green mature stage (Burg and Burg, 1962). In Bangladesh a considerable amount of papaya is being spoiled due to prevailing high temperature and humidity. Its edible and marketing quality deteriorates rapidly, once it is fully ripe. Papaya fruits are susceptible to many fungal diseases causing enormous loss to quality of fruits. Reduction of postharvest losses by prolonging the shelf life of papaya can improve the present situation. Harvesting at proper maturity stage is a very important determinant for storage life and final fruit quality. If fruits are harvested at improper maturity, it can lead to uneven ripening and over ripe fruits (Ceponis and Butterfield, 1973).

Heat treatments at different temperatures with appropriate time can be successfully applied for the disinfestations of disease and insect pests in fresh fruit (Armstrong, 1994; Couey, 1989). Hot water treatment of papaya at $49^{\circ} \mathrm{C}$ for 20 minutes can control postharvest decay, and it has been commercially used in Hawaii for more than 30 years. Recently, there have been increased efforts to discover new preservative compounds derived from natural sources (e.g. carnauba, paraffin, shellac, beeswax and chitosan), having no known effects on human health (Vargas et al.,2008). Chitosan, which has a chemical structure close to, that of cellulose has long been known to protect perishable foods from deterioration by reducing dehydration and respiration, maintaining the textural quality (Islam et al., 2015; No et al., 2007). In Bangladesh, spoilage of papaya during storage causes a serious problem to traders and consumers. Therefore, developing appropriate storage methods for extending the shelf life and reducing disease incidence and severity of papaya is utmost important.

\section{Materials and Methods}

The investigation was carried out at the Laboratories of the Department of Horticulture, Agricultural Chemistry, Bangladesh Agricultural University, Mymensingh during the period from June to October 2018. Papaya variety Shahi (BARI Papaya-1) was selected as experimental material. The study consisted of two factors, which were maturity stages and postharvest treatments. The experiment was laid out in a completely randomized design (CRD) with 3 replications of 5 fruits per replication. A total of 240 unblemished fruits of more or less uniform in size, shapes were harvested manually and cast-off. Two maturity stages- maturity index I (mature green) and maturity index II (0-10\% yellowing of fruit) and four postharvest treatments- control (ambient condition, $25 \pm 2^{\circ} \mathrm{C}$ ), hot water treatment (fruits treated at $50 \pm 2^{\circ} \mathrm{C}$ for 10 minutes), chitosan coating (2000ppm chitosan solution), hot water treatment + chitosan coating were used in the experiment. One hundred and twenty (120) mature green fruits were selected for maturity index I and other, 120 same sizes and $10 \%$ yellowing fruits were selected for maturity index II. Among all the fruits of each treatment, 5 fruits were used for destructive sampling at 3 days interval to investigate several parameters including shelf life, disease incidence and disease severity.

Shelf life: Shelf life of papaya fruits as influence by different storage treatments and maturity stages were calculated by counting the days required to ripe fully as to retaining optimum marketing and eating qualities. 
Assessment of percent disease incidence: The fruits were critically examined every day for the appearance of rot. The incidence of fruit rot was recorded every $3^{\text {rd }}$ day. The first count was made at the $3^{\text {rd }}$ day of storage. The fruit rot of papaya was identified by the visual comparison with those of the symptoms already published. The incidence of fruit rot was calculated as follows:

$\%$ Disease incidence $=\frac{\text { Number of infected fruits }}{\text { Total number of fruits under study }} \times 100$

Assessment of percent disease severity: The percentage fruit skin disease was recorded five times starting at the $3^{\text {rd }}$ day of storage. All the infected fruits were selected to determine percent fruit area infected. The percentage fruit area diseased was measured based on eye estimation.

Statistical analysis: The collected data on various parameters were statistically analyzed using MSTAT statistical package. The means for all the treatments were calculated and analysis of variance (ANOVA) for all the parameters was performed by F-test. The significance of difference between the pairs of means was compared by least significant difference (LSD) test at the $1 \%$ and $5 \%$ levels of probability (Gomez and Gomez, 1994).

\section{Results and Discussion}

Disease incidence: There was significant variation in the incidence of disease. Trend to increase disease incidence day by day. Maturity index II had highest $(93.59 \%)$ in disease incidence than maturity index I $(84.92 \%)$ at the $12^{\text {th }}$ day of storage (Figure 1). Disease incidence was higher in maturity stages II than maturity stages I fruits (Rashid et al. 2015). In case of postharvest treatments, Hot water + chitosan coating $(82.30 \%)$ treatments were the best for preventing disease incidence at $12^{\text {th }}$ day of storage (Figure 2). The lowest $(75.25 \%)$ disease incidence was found in the combination of $\mathrm{M}_{1} \mathrm{~T}_{3}$ (Maturity index $\mathrm{I} \times$ hot water+chitosan coating) than all other combinations at the $12^{\text {th }}$ day of storage (Table 1).

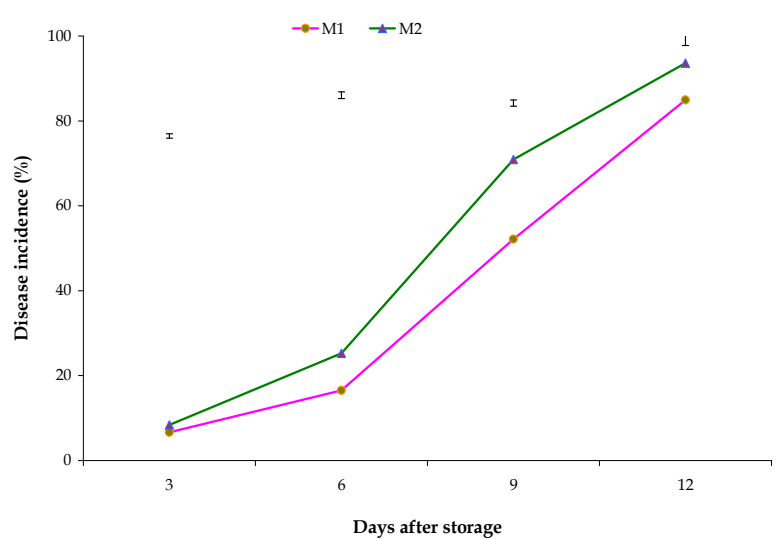

Figure 1. Main effect of maturity stages on disease incidence (\%) of papaya. $\mathrm{M}_{1}=$ Maturity index I (Mature green), $\mathrm{M}_{2}=$ Maturity index II (0-10\% yellowing of fruit), The vertical bars represent LSD at $1 \%$ level of significance.

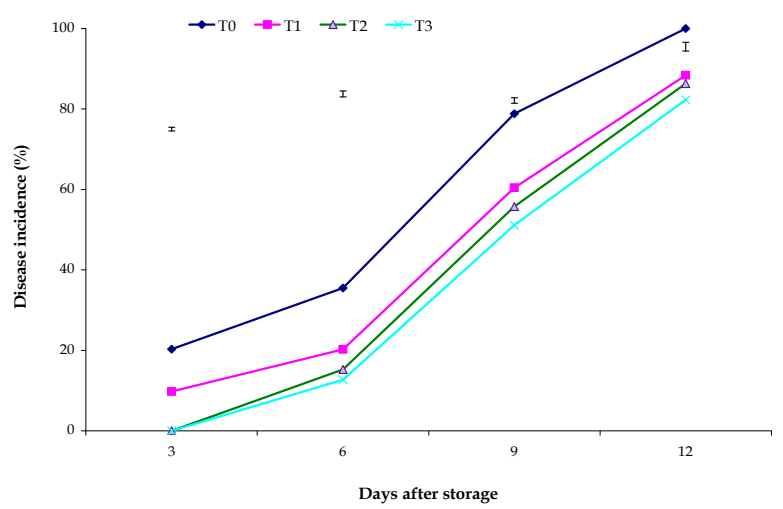

Figure 2. The main effect of postharvest treatments on disease incidence $(\%)$ of papaya. $\mathrm{T}_{0}=\mathrm{Control}$ (ambient condition, $25 \pm 2^{\circ} \mathrm{C}$ for 10 minutes), $\mathrm{T}_{1}=$ Hot water treatment (fruits treated at $50 \pm 2^{\circ} \mathrm{C}$ for 5 minutes), $\mathrm{T}_{2}=$ Chitosan coating (2000ppm Chitosan solution), $\mathrm{T}_{3}=$ Hot water + Chitosan coating. The vertical bars represent LSD at $1 \%$ level of significance.

Disease severity: The fruit surface disease was significantly influenced by the maturity index I, maturity index II and the postharvest treatments. The higher $(76.76 \%)$ severity level was found with 
increasing trend in maturity index II fruits than maturity index I $(68.78 \%)$ at $12^{\text {th }}$ day of storage (Figure $3)$.

Table 1. Combined effects of maturity stage and postharvest treatment on percent disease incidence at different days after storage (DAS) of papaya.

\begin{tabular}{|l|l|l|l|l|}
\hline \multirow{2}{*}{$\begin{array}{l}\text { Treatment } \\
\text { combination }\end{array}$} & \multicolumn{4}{|c|}{$\begin{array}{c}\text { Disease incidence (\%) at } \\
\text { different days after storage, DAS }\end{array}$} \\
\cline { 2 - 5 } & 3 & 6 & 9 & 12 \\
\hline $\mathrm{M}_{1} \mathrm{~T}_{0}$ & 19.25 & 26.67 & 64.32 & 100.00 \\
\hline $\mathrm{M}_{1} \mathrm{~T}_{1}$ & 7.27 & 16.21 & 55.52 & 84.25 \\
\hline $\mathrm{M}_{1} \mathrm{~T}_{2}$ & 0.00 & 12.18 & 46.27 & 80.18 \\
\hline $\mathrm{M}_{1} \mathrm{~T}_{3}$ & 0.00 & 11.15 & 42.62 & 75.25 \\
\hline $\mathrm{M}_{2} \mathrm{~T}_{0}$ & 21.30 & 44.30 & 93.38 & 100.00 \\
\hline $\mathrm{M}_{2} \mathrm{~T}_{1}$ & 12.30 & 24.25 & 65.35 & 92.50 \\
\hline $\mathrm{M}_{2} \mathrm{~T}_{2}$ & 0.00 & 18.35 & 65.25 & 92.50 \\
\hline $\mathrm{M}_{2} \mathrm{~T}_{3}$ & 0.00 & 14.20 & 59.65 & 89.34 \\
\hline $\mathrm{LSD}_{0.05}$ & 2.62 & 4.07 & 3.81 & 6.04 \\
\hline $\mathrm{LSD}_{0.01}$ & 3.61 & 5.61 & 5.24 & 8.32 \\
\hline $\begin{array}{l}\text { Level of } \\
\text { significance }\end{array}$ & $*$ & $* *$ & $* *$ & $* *$ \\
\hline
\end{tabular}

$* *=$ Significant at $1 \%$ level of probability, * = Significant at $5 \%$ level of probability, $\mathrm{M}_{1}=$ Maturity index I (Mature green), $\mathrm{M}_{2}=$ Maturity index II (0-10\% Yellowing of fruit). $\mathrm{T}_{0}=$ Control (ambient condition, $25 \pm 2^{\circ} \mathrm{C}$ for 10 minutes), $\mathrm{T}_{1}=$ Hot water treatment (fruits treated at $50 \pm 2^{\circ} \mathrm{C}$ for 5 minutes), $\mathrm{T}_{2}=$ Chitosan coating (2000ppm Chitosan solution), $\mathrm{T}_{3}=$ Hot water + Chitosan coating.

Disease severity in chitosan coating (49.24\%) followed by hot water treated fruits was the best for controlling disease severity at the $12^{\text {th }}$ day of storage (Figure 4). The minimum $(45.25 \%)$ disease severity was recorded in $\mathrm{M}_{1} \mathrm{~T}_{3}$ (Hot water+chitosan coating) combinations at the $12^{\text {th }}$ day of storage (Table 2). Similar result was also reported by Rashid et al., (2019) where the authors reported that where it was reported that the incidence and severity of surface fungal infections including anthracnose were significantly reduced by the combined treatment compared to single application of chitosan or hot water treatment. Disease incidence and severity level low in hot water+chitosan coating treated fruits due to chitosan coating around the fruit surfaces. Mondal et al., (2011) observed postharvest treatment reduces disease incident and disease severity in banana. Ali et al. (2010) reported that lowest disease incidence and severity in chitosan coating fruits and highest in untreated fruits in papaya.

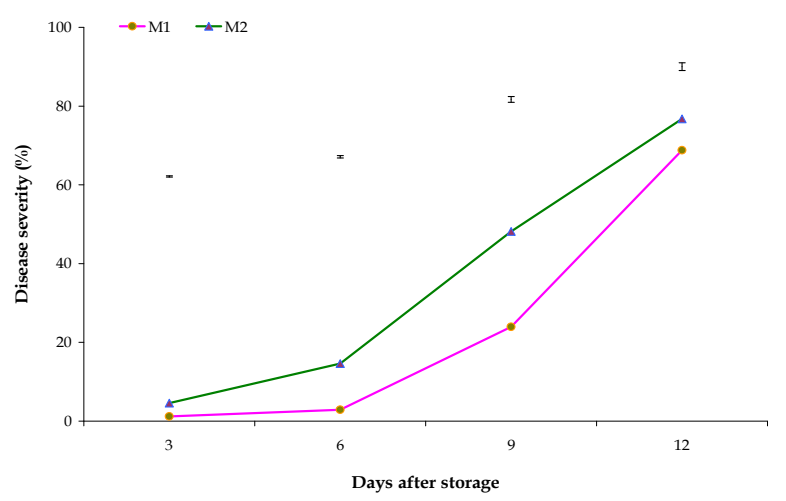

Figure 3. Main effect of maturity stages on disease severity (\%) of papaya. $\mathrm{M}_{1}=$ Maturity index I (Mature green), $\mathrm{M}_{2}=$ Maturity index II ( 0 $10 \%$ Yellowing of fruit).The vertical bars represent LSD at $1 \%$ level of significance.

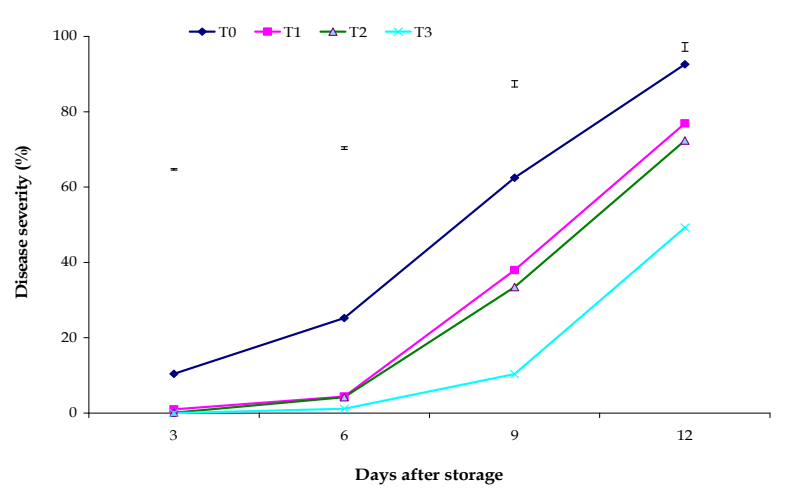

Figure 4. The main effect of postharvest treatments on disease severity (\%) of papaya. $\mathrm{T}_{0}=$ Control (ambient condition), $\mathrm{T}_{1}=$ Hot water treatment (fruits treated at $50 \pm 2^{\circ} \mathrm{C}$ for 5 minutes), $\mathrm{T}_{2}=$ Chitosan coating (2000ppm Chitosan solution), $\mathrm{T}_{3}=$ Hot water + Chitosan coating. The vertical bars represent LSD at $1 \%$ level of significance. 
Table 2. Combined effects of maturity stage and post harvest treatment on percent disease severity at different days after storage (DAS) of papaya.

\begin{tabular}{|l|l|l|l|l|}
\hline \multirow{2}{*}{$\begin{array}{l}\text { Treatment } \\
\text { combination }\end{array}$} & \multicolumn{5}{|l}{$\begin{array}{l}\text { Disease severity (\%) at different days } \\
\text { after storage (DAS) }\end{array}$} \\
\cline { 2 - 5 } & 3 & 6 & 9 & 12 \\
\hline $\mathrm{M}_{1} \mathrm{~T}_{0}$ & 4.50 & 8.25 & 32.45 & 85.23 \\
\hline $\mathrm{M}_{1} \mathrm{~T}_{1}$ & 0.25 & 1.45 & 29.27 & 75.26 \\
\hline $\mathrm{M}_{1} \mathrm{~T}_{2}$ & 0.00 & 1.27 & 24.54 & 69.38 \\
\hline $\mathrm{M}_{1} \mathrm{~T}_{3}$ & 0.00 & 0.50 & 9.50 & 45.25 \\
\hline $\mathrm{M}_{2} \mathrm{~T}_{0}$ & 16.36 & 42.25 & 92.50 & 100.00 \\
\hline $\mathrm{M}_{2} \mathrm{~T}_{1}$ & 1.75 & 7.35 & 46.67 & 78.50 \\
\hline $\mathrm{M}_{2} \mathrm{~T}_{2}$ & 0.25 & 7.15 & 42.35 & 75.30 \\
\hline $\mathrm{M}_{2} \mathrm{~T}_{3}$ & 0.00 & 1.75 & 11.25 & 53.23 \\
\hline $\mathrm{LSD}_{0.05}$ & 0.71 & 1.39 & 3.44 & 4.61 \\
\hline $\mathrm{LSD}_{0.01}$ & 0.98 & 1.92 & 4.73 & 6.35 \\
\hline $\begin{array}{l}\mathrm{Level}_{\text {of }} \\
\text { significance }\end{array}$ & $* *$ & $* *$ & $* *$ & $* *$ \\
\hline
\end{tabular}

** = Significant at $1 \%$ level of probability, $\mathrm{M}_{1}=$ Maturity index I (Mature green), $\mathrm{M}_{2}=$ Maturity index II $(0-10 \%$ yellowing of fruit), $\mathrm{T}_{0}=$ Control (ambient condition, $25 \pm 2^{\circ} \mathrm{C}$ for 10 minutes), $\mathrm{T}_{1}=$ Hot water treatment (fruits treated at $50 \pm 2^{\circ} \mathrm{C}$ for 10 minutes), $\mathrm{T}_{2}=$ Chitosan coating $(2000 \mathrm{ppm}$ Chitosan solution), $\mathrm{T}_{3}=$ Hot water + Chitosan coating.

Shelf life: Effect of maturity stages, postharvest treatments and combined effect on shelf life extension were significant. The longer shelf life (12.64 days) was obtained in maturity index I fruits than maturity index II (12.18 days) fruits of papaya (Figure 5). The highest shelf life (15.00 days) was observed due to postharvest treatments in fruits hot water+chitosan coated fruits followed by chitosan coating (14.35 days). However, the shortest shelf life ( 8.89 days) was observed in the control fruits (Figure 6). The longest shelf life (15.20 days) caused by combined effect was observed in maturity stages I of hot water+chitosan coated fruits and shortest shelf life of 8.52 days observed in maturity index II and control fruits (Figure 7).The delay in ripening on chitosan coated fruits can occur due to the lower capacity of these fruits in producing ethylene, since this hormone has a stimulation role in the general metabolism, and seems to be implicated in the activation and regulation of some enzymes involved in ripening(Gomez et al., 1999). Longest shelf lives were found 5 weeks in chitosan treated fruit in papaya by Ali et al., (2010).

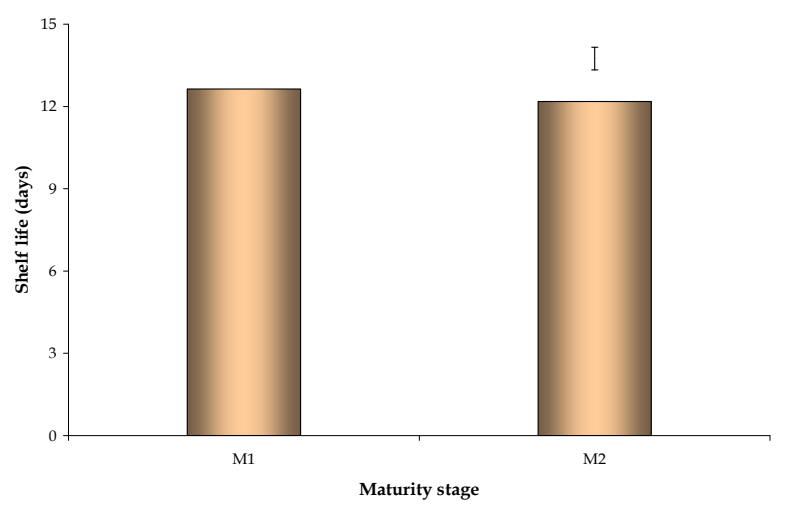

Figure 5. Main effect of maturity stages on Shelf life of papaya. $\mathrm{M}_{1}=$ Maturity index I (Mature green), $\mathrm{M}_{2}=$ Maturity index II $(0-10 \%$ yellowing of fruit). The vertical bars represent LSD at $1 \%$ level of significance.

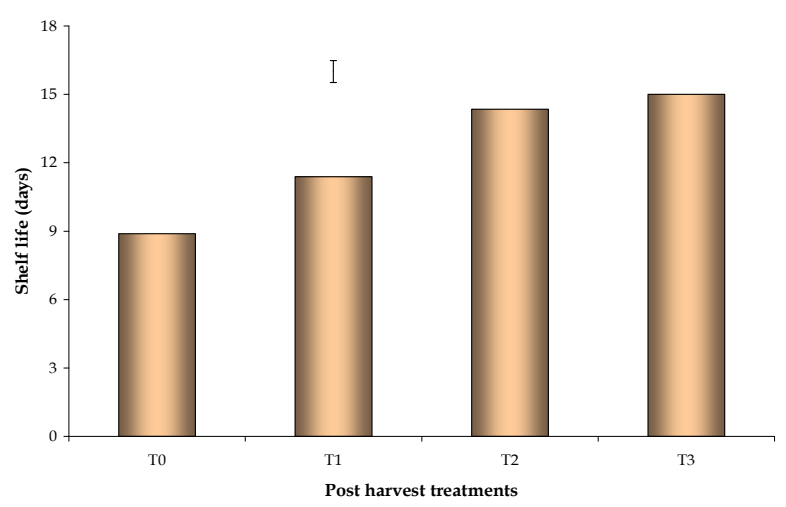

Figure 6. The main effect of postharvest treatments on shelf life of papaya. 


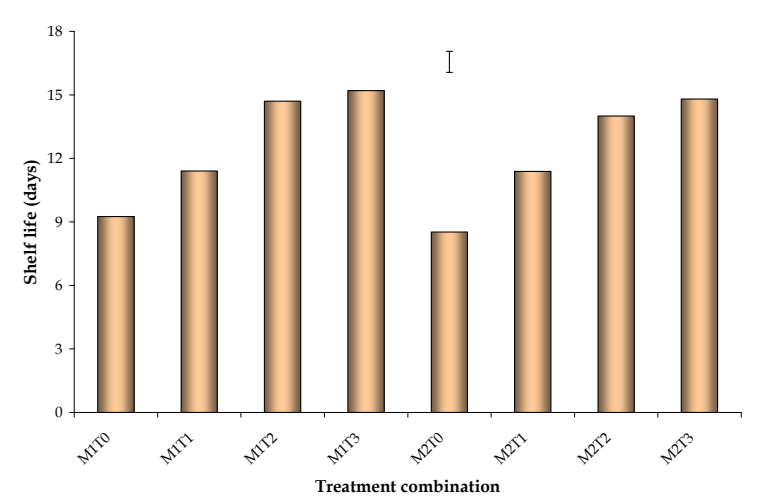

Figure 7. Combined effects of maturity stage and post harvest treatment on shelf life of papaya. $\mathrm{M}_{1}$ $=$ Maturity index I (Mature green), $\mathrm{M}_{2}=$ Maturity index II (0-10\% yellowing of fruit). $\mathrm{T}_{0}=$ Control (ambient condition, $25 \pm 2^{\circ} \mathrm{C}$ for 10 minutes), $\mathrm{T}_{1}=$ Hot water treatment (fruits treated at $50 \pm 2^{\circ} \mathrm{C}$ for 10 minutes), $\mathrm{T}_{2}=$ Chitosan coating (2000ppm Chitosan solution), $\mathrm{T}_{3}=$ Hot water + Chitosan coating. The vertical bars represent LSD at $1 \%$ level of significance.

\section{Conclusion}

Considering the above mentioned findings, it is evident that maturity stage I and hot water with chitosan treated fruits better than maturity stage II and chitosan coating, respectively.Further studies are suggested to carry out to examine the effects of chitosan solution and gel with series of concentrations on shelf life and disease incidence and severity of papaya fruits grown in Bangladesh.

\section{Acknowledgements}

The authors would like to thank Bangladesh Agricultural University Research System (BAURES),Mymensingh for funding this work and gratefully acknowledge the assistance of Professor Dr. HariPada Seal, Department of Agricultural Chemistry, Bangladesh Agricultural University, Mymensingh to chitosan preparation from shrimp shell.

\section{References}

Ali A, Muhammed MTM, Sijam K, Siddiqui Y (2010). Effect of chitosan coatings on the physicochemical characteristics of Eksotika II papaya (Carica papaya L.) fruit during cold storage. Journal of Food Chemistry, 124:620-627.

Armstrong JW (1994). Heat and cold treatments. In: R.E. Paull and J. W. Armstrong (eds.).Insect pests and fresh horticultural products: Treatments and responses. $\mathrm{CAB}$ Intl.,Wallingford, U.K., p. 103-119.

Badillo VM (1971). Monografia de la familie Caricaceae. Associacion de Professores, Universided Cental de Venezuela, Maracay, Venezuela.

BBS (2018). Yearbook of Agricultural Statictics (2017). Bangladesh Bureau of Statictics, Ministry of Planning, Government People's Republic of Bangladesh. p. 210.

Burg SP, Burg EA (1962). Role of ethylene in fruit ripening.Plant Physiology, 37: 179-189.

Ceponis MJ, Butterfield JE (1973). The nature and extent of retail and consumerlosses in apples, oranges, lettuce and peaches, strawberries and potatoes marketedin Greater New York.US Dept. Agric. Market Research Report No. 996.

Chan HT, Tang CS (1979) The chemistry and biochemistry of papaya. In:InglettGE, Charolambous G (Eds) Tropical Foods (Vol I), Academic Press, New York.

Couey HM (1989). Heat treatment for control of postharvest diseases and insect pests offruits.Horticultural Science, 24:198-202.

Gomez MLPA, Lajolo FM, Cordenunsi BR (1999). Metabolismo de carboidratos durante $\mathrm{O}$ amadurecimento domamao (Carica papaya L. cv. Solo): influéncia da radiaçãogama. Ciéncia e Tecnologia de Alimentos, 19: 246-252. https:// doi.org/10.1590/S0101-20611999000200017.

Islam MS, Mondal MF (2011). Effects of Application Various Plant Extracts on Physico-Chemical Changes and Diseases of Banana. Journal of the 
Bangladesh Society for Agricultural Science and Technology, 8 (3\&4):137-142.

Islam MA, Haque ME, Hossain MK, Hossain S. (2015). Investigation of formalin and ethepon in some fruits of three local markets of Mymensingh District using Gas Chromatograph. J. Bangaldesh Agril. Univ. , 13(1): 7-12.

Mondal MF, Bose SK (2007). Physico-chemical changes in papaya fruits during storage. Journal of the Bangladesh Society for Agricultural Science and Technology, 4: 145-148.

Mondal MF, Islam MS (2011). Effects of Application Various Plant Extracts on Shelf Life and Quality of Banana.Journal of the Bangladesh Society for Agricultural Science and Technology, 8 (3\&4): 143-148.

No HK, Meyers SP, Prinyawiwatkul W, Xu Z (2007). Applications of chitosan for improvement of quality and shelf life of foods: A review. Journal of Food Science, 72:87-100.
Rashid MHA, Borman BC, Hasna MK, Begum HA (2019). Effects of non-chemical treatments on postharvest diseases, shelf life and quality ofpapaya under two different maturity stages. Journal of Bangladesh Agricultural University, 17(1): 14-25. https://doi.org/10.3329/jbau.v17 i1. 40658.

Rashid MHA, Grout BWW, Continella A, Mahmud TMM (2015). Low-dose gamma irradiation following hot water immersion of papaya (Carica papaya L.) fruits provides additional control of postharvest fungal infection to extend shelf life. Radiation Physics and Chemistry, 110: 77-81.

Singh ID (1990). Papaya. Oxford and IBH Publishing Company Private Limited, New Delhi, p.192.

Vargas M, Pastor C, Chiralt A, McClements DJ, González-Martínez C (2008). Recent advances in edible coatings for fresh and minimally processed fruits. Critical Reviews in Food Science and Nutrition, 48:496-511. 